\title{
H. S. Skovoroda's Religious and Philosophical Ideas (interpreted by Mahdalyna Laslo-Kutsiuk)
}

\author{
IRYNA KAIZER, OLHA NASTENKO, TETIANA NYKYFORUK, \\ MARTA MAKSYMIUK, VOLODYMYR ANTOFIYCHUK
}

\begin{abstract}
Hryhorii Savych Skovoroda's religious and philosophic ideas have attracted considerable attention in academic scientific discourse in postcommunist Ukraine. This is due not only to the humanistic-democratic paradigm of modern transformations in society, but also the methodological principles of historical and philosophical knowledge. We have tried to make a syncretic analysis of Skovoroda's life and creativity based on the works of Romanian literary critic Mahdalyna Laslo-Kutsiuk (1928-2010), in particular by analysing the origins of Skovoroda's philosophical doctrines, rethinking the Bible and specificity of his literary works.

Skovoroda's greatness lies in the fact that without losing his identity against the background of a rather fundamental philosophical tradition in Ukraine, he occupied and still occupies perhaps the most avant-garde position. $\mathrm{He}$ was one of the first philosophers to restore and develope the phenomenon of wisdom in new European civilisation, which was removed by the overall project of rationally-epistemological and rationally-scientific interpretations of philosophy after the ancient times. Analysis of the latest studies of Slavic and Western investigations of Skovoroda shows that this branch is interdisciplinary. Philosophers, historians, culture experts, literary critics, specialists in the history of religion have studied the heritage of this prominent Ukrainian philosopher. Expansion of the methodological spectrum started in the 1990s, meaning that the art of Skovoroda should be apprehended as penetrating synthetic phenomena in which the essential components of the Baroque world-view are combined with the culture of late antiquity, patristic tradition and even European humanism.
\end{abstract}

Keywords: H. Skovoroda; M. Laslo-Kutsiuk; the Bible; hermeneutics; writerphilosopher

\section{Introduction}

Hryhorii Skovoroda has an important place among Ukrainian writers and became the object of study for Romanian researcher M. Laslo-Kutsiuk. According to Laslo-Kutsiuk, Skovoroda was ahead of his contemporaries for 
several decades with his philosophical and religious system and world-view, which "... is sometimes strange to read, as [...] absolute agreement with antique scientific concepts intermingles with biblical symbolism” (Laslo-Kucyuk 1994: 90, all quotes translated by the authors of the paper).

Literary critics have studied Skovoroda's life and creative career using world and Ukrainian literature, biblical and mythological archetypes. They have considered the personality of Skovoroda and used methods such as psychoanalysis, comparative literary criticism, hermeneutics and intertextual analysis.

Over the last decades Ukrainian and foreign researchers, such as L. Hnatyuk, M. Popovych, L. Ushkalov, E. von Erdmann, O. Marchenko, L, Sofronova, and M. G. Bartolini, have considered the aesthetic and philosophical principles of perception of Skovoroda's world. The philosophical aspect of the comprehension of antique topics and images by Ukrainian medieval artist has been studied in works by Yu. Barabash, N. Korzh, D. Chyzhevskiy, I. Huzar, I. Ivanio, D. Kyryk, D. Olyanchyn and others.

The Kyiv Mohyla Academy and its surroundings played a significant role in the formation of philosophical, aesthetic and clerical ideas in the cultural life of Ukraine in the $17^{\text {th }}$ and $18^{\text {th }}$ centuries, and on Skovoroda's world-view. O. Abramov, V. Nichyk and others have written about this in their works.

While studying at the Mohyla Academy [...], Skovoroda mastered Greek, Latin and the basics of Hebrew; he studied rhetoric and poetry; he learnt Latin literature and philosophy, and also [...] Greek and Latin patristic idea. [...] These diverse intellectual interests, which include the Bible, antique culture, patristics, humanism and Ukrainian Baroque culture developed into the corpus of his art, creating a compact intertextual cloth, the deciphering of which is topical for a completest understanding of Skovoroda's ideas and contemplative methods. (Bartolini 2017: 9)

The doctoral dissertation of T. Shevchuk "Antique Heritage in the Artistic Perception of H. Skovoroda" (Ševčuk 2010) is a detailed comparative investigation dedicated to Skovoroda's study of antique heritage.

\section{Discussion}

Laslo-Kutsiuk's writing dedicated to Skovoroda or thematic overviews of the greatest Ukrainian philosopher show the reader one very important characteristic of Skovoroda, i.e. he was thoroughly "different", absolutely marginal and a genius. He created a peculiar ontological philosophy, implemented it into 
reality and manifested his dogmas of purity and lightness of mind until the last minute of his terrestrial existence.

In the $18^{\text {th }}$ century, the age of glorification of the human mind, the worship of which replaced religion by the time of the French revolution, Ukrainian philosopher Hryhorii Skovoroda took the opposite path. He decided to rescue the tradition that had been founded in the period of antiquity [...]. Skovoroda believed that, although any scientific progress was a triumph of mind, it did not justify the disregard of something that could be interesting for people, specifically, understanding of their destiny, their sense of life and their place in the universe because, having understood it, they would realise their responsibility for their actions and society would have a better foundation (Laslo-Kucyuk 1994: 78).

The majority of researchers of Skovoroda, for example D. Chyzhevskyi, L. Ushkalov, S. Kvit, and M. Laslo-Kutsiuk point out the asceticism of the writer's mind, who immersed into studying ancient authors, mainly Greek, in order to learn wisdom and knowledge about human nature and gain harmony of body and soul:

According to him, the wisdom of achievement of happiness does not consist of the accumulation of material benefits, but in finding calmness in the soul. Moreover, this is possible only when humanity understands its spiritual destination. (Laslo-Kucyuk 1994: 78)

Laslo-Kutsiuk thinks that the specificity of Skovoroda's philosophical doctrine and literary works consists in the fact that Skovoroda looked for an explanation for the enigma of human happiness and harmony not only in works of antique authors but also in the Bible ${ }^{1}$. This made Skovoroda's unique creativity an intertextual achievement in which pre-Christian beliefs of the Ancient East, Ancient India, and the apocryphal and canonised texts of the Old Testament interacted with Slavic mythology and folklore.

Concerning the writer's interpretation of the Bible, he "understood it in his own way, not dogmatically, as did Vyshenskyi or Velychkovskyi, although, if one pays attention to their moral criteria he would have completely

1 H. Skovoroda experienced a deep mystical shock in the garden of Trinity monastery in Ohtyrka in about 1770 . According to him, he felt an extraordinary movement inside, the whole world disappeared for him, and only the feeling of love, reliability, eternity vitalised his existence. The philosopher penetrated inside of his soul and devoted his personality to submission to the God spirit, becaming a wandering philosopher. 
corresponded to the latter as he was an ascetic recluse who did not consume meat and wine" (Laslo-Kucyuk 1994: 79).

Laslo-Kutsiuk concludes with a subtle psychoanalytic approach to the problem of the "differing" and reclusiveness of the philosopher, saying that something that was evidence of orthodoxy for some people became one more reason for Skovoroda to be suspicious. Some claimed the was a heretic for his refusal to drink wine and eat meat, and a Manichean. Manicheism is the gnostic doctrine that consists of various religious notions, a syncretic religious philosophy created by the Persian Mani, or Manes. It is a dualistic doctrine about the struggle of good and evil that required the strictest discipline from its circle of adepts, especially concerning nutrition, sex life and physical work (Eliade 1987). However, Vyshenskyi, who considered everything terrestrial as the creation of the devil, was probably a bigger Manichean. "Ale tak uzhe vedetsia u sviti, - liudy nikoly nikomu ne proshchayut duhovnu vyshchist za sebe" ("But this is already happening in the world, - people never forgive anyone's spiritual superiority', Laslo-Kucyuk 1994: 79).

Nevertheless, as Laslo-Kutsiuk says, the statement has not been investigated by those researchers who are working on the effect of the Reformation on Skovoroda:

But it seems to us, that there were specific impacts at least in freedom with which Skovoroda interpreted theological topics. It is not accidentally that both Skovoroda and Phlatsius were accused in the same kind of heresy - in Manicheism. Besides, Skovoroda quotes August Buchner in his philological extracts, he was a Latin language German poet and literary man, who lived between 1591-1661 and he was a professor at Wittenberg University, the main ideological center of the Reformation. (Laslo-Kucyuk 2000: 28)

Laslo-Kutsiuk uses hermeneutics to carry out an analysis of Skovoroda's creative works, according to which hermeneutics preserves its meaning as a science of the interpretation of ancient texts, having a whole range of auxiliary branches together with comparative-typological and genetic methods. The main task of hermeneutics is the reproduction of the most complete and checked text of the works of ancient writers form numerous fragments and versions (Laslo-Kucyuk 2000: 28). Therefore, we often see accurate and professional remarks about one or other version of the author's works, about his understanding of the Bible or intuitive recreation of ideas from other sacred books (the Upanishads, Septugiata) on the pages of Laslo-Kutsiuk's works. For example, we see a way of correctly understanding the Talk of Five Travellers treatise and Skovoroda's constant allusions to the text and archetype of the 
Bible in particular (specifically, the $18^{\text {th }}$ psalm) in the Apotheosis of Light in Creative Works of Hryhorii Skovoroda.

The author's early-Christian and even pantheistic maxim that God has put His settlement in the sun made Laslo-Kutsiuk look for the origin of this in the Old Testament epigram "This sentence seemed to be an inaccurate quote from the Old Testament or translators' mistake of psalms to the Greek language. However, Qumran Caves Scrolls finally explained that Septugiata $\left(2^{\text {nd }}\right.$ century $\mathrm{BC}$ ) was a translation made from older versions than those which composed modern Jewish canon based on studying of Masoretes of the 10th century AD" (Laslo-Kucyuk 1994: 96).

Such accurate and comprehensive attributions to the ancient texts raised the investigation of the Romanian researcher to a high level of comparative literary study and gave the possibility of seeing how Skovoroda's creative work is full of conscious and unconscious allusions to many sacred books, even to those dating from before Christ. Eventually, Laslo-Kutsiuk claims that "we can only be astonished by Skovoroda's insight, who so accurately guessed the oldest layers, remains of polytheism in the texts of the psalms, although he certainly did not consider them such, as he was inclined to Apotheosis, idolising the light” (Laslo-Kucyuk 1994: 97).

Laslo-Kutsiuk develops Skovoroda's understanding and reconsideration of the Bible with the help of hermeneutics as showing the polysemy of the Bible, which was popular during Baroque period stimulated the development of a phenomenon "which chronologically completes Ukrainian Baroque biblical hermeneutics, namely, Hryhorii Skovoroda's doctrine about 'symbolic secret imaginative world of the Bible"' (Laslo-Kucyuk 2000: 29). Skovoroda was not the only person interested in the hermeneutics of Sacred Scripture, and Ukrainian Baroque in general can be characterised as thoroughly imbued with the hidden meaning of biblical texts. However, Skovoroda "did not admit any reason, but symbolic one by literal and moral senses of Sacred Scripture. In his opinion, the natural calm of the Bible is "to combine figures and symbols by historical and moral hypocrisy” (Uškalov 2004: 80).

Therefore, together with the above-mentioned investigators of the author's creative works, Laslo-Kutsiuk emphasizes that the writer-philosopher used the method of allegorical interpretation of the Bible, because "Skovoroda was an allegorical writer in his comments and his parables, however, as a Baroque author, he went further than medieval allegory, contributing to the elements of his works of amazement, vivid visualisation and numerous allusions, namely hints, which are sometimes understood by only the initiated" (Laslo-Kucyuk 1994: 88). 
Laslo-Kutsiuk's idea about chewing reading material is connected with her hermeneutic reading of. Skovoroda's works. That was outlined after reconsideration by Laslo-Kutsiuk of the reformer Buchner's statement:

It is necessary to read and reread not many authors, but the best ones [...] If you do not chew food, then only a small part of it will be consumed, because it will remain undigested. In the same way, if you do not take something that you need from authors, and you do not thoughtfully and carefully study them, then you will never convert it into juice and blood. (Laslo-Kucyuk 2000: 29)

Therefore, according to Laslo-Kutsiuk, the enthusiasm for word semantics is characteristic of Skovoroda, "he greedily catches their meaning in different languages available for him” (Laslo-Kucyuk 2000: 29). Regarding more detailed study of this, Laslo-Kutsiuk refers the reader to Kharkiv Skovoroda expert Leonid Ushkalov. His book The World of Ukrainian Baroque (Uškalov 1994, "Biblical Hermeneutics" chapter) scrupulously analyses the messianism of Baroque authors, their attempt to read numerous Old Testament pages as a prediction of Christ coming. Skovoroda affirmed in one letter, that he was born to give an interpretation of the Bible. His life acquired a completely new sense when he realised that he was a "Bible lover" at the age of thirty. Skovoroda singled out the Bible as belonging to a unique ontological sphere (symbolical world); only this text is a guide of the human heart into the territory of the Holy Spirit. Skovoroda dedicated the whole row of his works to the art of interpretation of the Holy Script, in particular, such treatises as "Silenus Alcibiadis", "Lot's wife", and the dialogue "Serpentine Flood" (Uškalov 2004: 86).

Skovoroda's interpretation of the Bible is connected with one of the most significant maxims of his creative works and philosophy of life: Recognize Yourself. That is expressed in freedom and peace of mind, comprehending God's truth, and concentrating on self-cognition and self-improvement, which constitute the concept of happiness, i.e. "finding peace of mind" for the writer. Furthermore, this is possible only when humanity understands its spiritual purpose (Laslo-Kucyuk 1990: 51). Continuing the chain of definitions that characterise Skovoroda's spiritual idyll, Laslo-Kutsiuk concludes that, according to Skovoroda, understanding God in oneself is a precondition to achieving freedom (Divine Nature, God's Spirit), i.e. genuine nature, which is accordingly connected with understanding freedom as a unique spiritual state. Skovoroda was sure that people must be most interested in "understanding their purpose, sense of their lives and place in the universe because comprehending this, people will conceive their responsibility for their actions, society will have better grounds than now" (Laslo-Kucyuk 1990: 51). The wealth of the spirit was his ideal, as well as purity of heart, peace of spirit and 
being a coherent person who could resist the unworthy temptation of the world. Establishment of pure soul and strong personality was the aim of his creativity and all his life, as well as that of Shevchenko. Another researcher of Ukrainian literature D. Chyzhevskyi had the same opinion. He noted that Skovoroda had paid special attention to learning about himself as the way of implementing the aim of terrestrial life. People had to understand that the source of happiness emerged from the depth of their being ${ }^{2}$. However, cognition, in general, is accessible for people only when God is present in the process of this cognition and self-cognition. In this way the category of happiness goes beyond theory and comes into the realm of vital morality, according to Skovoroda (Čiževskiy 2004).

Intertextual attribution in Skovoroda's literary and philosophical works concerns not only holy writing. A significant layer of palimpsest plots and characters belong to 'pagan' (rather than Greco-Roman) mythology, together with Christian canonical texts from which his academic education began. In particular, "in the Kyiv Mohyla academy class of poetics Skovoroda interpreted numerous mythological characters (Acteon, Amur, Ananke, Apollon, Ariadne, Astraea, Atlas, Bacchus, Venus, Ganymede, Hercules, giants, Diana, Oedipus, Aeneas, Ixion, Ir, Kronos, Laocoon, Mercury, Minerva, Morpheus, muses, Narcissus, Neptune, Odyssey, Orpheus, Saturn, sirens, sphinx, Tantalus, Typhon, Phaeton, Flora, fury, cyclops, Jupiter, Janus) mainly from the perspective of allegory, as well as within frames of Euhemerus' paradigm, according to which pagan gods were nothing like deified people” (Uškalov 2004: 86).

At the same time, Laslo-Kutsiuk emphasises that Skovoroda belonged among authors who paid great attention to the interpretation of symbols in the Bible and myths of antiquity.

Myth is a symbol, to which predicate is added action, which leads its movement. That is why the analysis of a myth must always take into account original symbols. There are a variety of such symbols in the Old Testament. They are the basis of ritual in both Jewry and Christianity. Later they were differently

2 Moreover, searching for the principles on which Skovoroda's philosophy is based, Chyzhevskyi tried to reveal parallels between his thought and the thought of other philosophers, and to find his 'spiritual brothers'. Chyzhevskyi did not analyse the effects of different philosophical streams on Skovoroda's world-view. However, he did search for a relationship in the understanding of the world and sense of life between Ukraine and representatives of other cultures. In order to do this Laslo-Kutsiuk first considered the system of Skovoroda's thought and then gave parallels from the history of world ideas in each chapter of his fundamental work Philosophy of H. S. Skovoroda. 
interpreted in the Talmud, Kabbalah, and Patristics as well. (Laslo-Kucyuk 2000: 82)

Greco-Roman philosophy had a significant effect on Skovoroda, which LasloKutsiuk always focuses her attention on. In particular, the chapter "Numbers of world-building", in Fire and Word, focuses on an analysis of the effect of Pythagoras' doctrine on Skovoroda's creativity. The doctrine of the other outstanding philosopher Socrates played a considerable role in Skovoroda's world perception. Laslo-Kutsiuk mentions that Skovoroda even chose the model of Socrates for himself, as he also wanted to live poorly and accepted death but did not refuse from his harmful convictions for the youth (LasloKucyuk 1994: 80).

Laslo-Kutsiuk writes about the enormous effect Philo of Alexandria had on Skovoroda's philosophical system. His doctrine attempted to interpret biblical cosmogonic legend as philosophical interpretation based on the doctrine of Greek philosophers about the divine mind or divine word (logos). This led Skovoroda to interpret the Bible as an allegorical work rather than a historical one. (Laslo-Kucyuk 1994: 82)

This was a great heresy at that time. However, the Russian orthodox church did not subject Skovoroda to persecution, as all of his works were manuscripts and distributed in only small numbers. Thus, in The Apotheosis of Light in the Works of Hryhorii Skovoroda, Laslo-Kutsiuk indicates that "Philo of Alexandria inspired Skovoroda for the apotheosis of light, that is, that the first had some influence on his ontological ideas" for the first time in Skovoroda study (Laslo-Kucyuk 1994: 82). Even D. Chyzhevskyi missed this moment. He was engaged in the beginnings of the study of Skovoroda's philosophy. Chyzhevskyi particularly studied the effect of Philo on the epistemology of Skovoroda, specifically the tendency to separate the spiritual from the physical. Skovoroda followed biblical and Greek postulates in identifying God and the word as His manifestation. However, Laslo-Kutsiuk claims that Skovoroda inclined the most to the doctrine of Jewish philosopher Philo of Alexandria, who had relied upon reflections of Greek philosophers and biblical dogmas. However, Laslo-Kutsiuk observed that unlike in the Bible, in both Philo and Skovoroda the Word did not occur as a direct order but as a conception and inspiration. This proves the allegory of reading sacred text by Jewish and Ukrainian philosophers.

Laslo-Kutsiuk repeatedly points out how Skovoroda was interested in the wisdom of the Ancient East. Talking about the symbolism of ancient philosophy, Skovoroda mentioned Egyptian hieroglyphs and connected ideas about God as the "eternal all-seeing eye" with Zoroaster, the conjectural author 
IRYNA KAIZER et al

of the Avesta (VII century BC). In addition, Skovoroda mentions India in his works several times (the dialogue The Ring, letters to Mykhailo Kovalynskyi). It is even possible to trace several similarities of the science of Skovoroda and ancient Indian philosophy. In particular, Laslo-Kutsiuk attempts to compare idea about transcendental light in The Upanishads and in the works of Dionysius the Areopagite, interpreted as a follower of ancient Indian philosophers, and Skovoroda's poetry, for example "About the Holy Supper" or "About Eternity". Laslo-Kutsiuk claims that "Skovoroda brought the philosophical concept into the treasury of Ukrainian culture, which has its source in far India” (Laslo-Kucyuk 1990: 51). In the same way, Skovoroda's concept of "affinity" is compared with the philosophy of the Bhagavad Gita (better to fail at your own dharma than to succeed at the dharma of another), and his introvert lifestyle with the lifestyle of a Buddhist sage (Dodonov 2002: 56-61).

\title{
Conclusions
}

Allegorical combinations of biblical, mythological and philosophical thinking have made the creativity of $\mathrm{H}$. Skovoroda a unique interpreted palimpsest:

$[\ldots]$ it is often strange to read as complete accordance with antique scientific concepts are incorporated with biblical symbols in Skovoroda [...]. The philosopher always headed to the light, absorbing the excellency of Greek philosophy and its understanding of balance as a basis of world-building and antique notions about the physiology and psycho-physiology of the human body. This idea preserved its topicality in the $18^{\text {th }}$ century in Skovoroda. (Laslo-Kucyuk 1994: 90-91)

Analysis of the latest studies of Slavic and Western Skovoroda study shows that this branch gravitates towards being inter-disciplinary. The heritage of this prominent Ukrainian philosopher has been investigated by philosophers, historians, culture experts, literary critics, specialists in the history of religion. Expansion of the methodological spectrum is connected with the tendency, which originated in the 1990s, to perceive the art of Skovoroda as being a synthetic phenomenon, where essential components of the Baroque outlook are combined with the culture of late antiquity, the patristic tradition and even European humanism.

\author{
Iryna Kaizer \\ irabosak06@gmail.com \\ Bukovinian State Medical University \\ UKRAINE
}


H. S. Skovoroda's Religious and Philosophical Ideas

\author{
Olha Nastenko \\ o_li@ukr.net \\ Bukovinian State Medical University \\ UKRAINE
}

\author{
Tetiana Nykyforuk \\ kuryluk235@ukr.net \\ Bukovinian State Medical University \\ UKRAINE
}

\title{
Marta Maksymiuk \\ maksymjuk@ukr.net \\ Bukovinian State Medical University \\ UKRAINE
}

\author{
Volodymyr Antofiychuk \\ antofiychuk@ukr.net \\ Yuriy Fed'kovych Chernitsi National University \\ UKRAINE
}

\section{Bibliography}

Bartolini, M. G. 2017. Piznaj samogo sebe. Neoplatonični džerela v tvorčosti G. S. Skovorodi. Kï̈v: Akademperiodika. = Бартоліні, М. Г. 2017. Пізнай самого себе. Неоплатонічні джерела в творчості Г. С. Сковороди. Київ: АкаАемперіодика.

Čiževskiy, D. 2004. Filosofiya G. S. Skovorodi. Harkiv. = Чижевський, А. 2004. Філософія Г. С. Сковороди. Харків.

Dodonov, R. 2002. Shidni motivi u filosfstvuvanni G. S. Skovorodi. - Materiali mižregional'noï naukovoï konferenciï "Filosofs' ko-etična spadščina G. S. Skovorodi ta duhovnij sviy syčasnoï lyudini”, 2. Donec'k, 56-61. = Аодонов Р. 2002. СхіАні мотиви у філософствуванні Г. С. Сковороди. - Матеріали міжрегіональної наукової конферениії "Філософсько-етична спадщина Г.С. Сковороди та духовний світ сучасної ююдии”, 2. Аонецьк, 56-61.

Eliade, M. 1987. Encyclopedia of Religions. USA: MacMillan.

Gnatyuk, L. 2002. Filosfija movi G. Skovorodi. - Ukraïns'ka mova, 1, 63-70. = Гнатюк, $\Lambda$. 2002. Фікософія мови Г. Сковороди. - Українська мова, 1, 63-70.

Guzar, I. 1995. Ukraïna v orbiti èvropejskoï misli. Vid Grigorija Skovorodi do Tarasa Ševčenka. Toronto. = Гузар, I. 1995. Україна в орбіті європейської мислі. ВіА Григорія Сковороди до Тараса Шевченка. Торонто.

Ivan'o, I. 1983. Filosofiya $i$ stil' mislennya G. Skovorodi. Kyiv. = Іваньо, I. 1983. Філософія і стильмислення Г. Сковороди. Київ.

Kirik, D. 1990. Skovoroda i grec'ka kul'tura. - Antična kul'tura i vitčiznyana filosfs'ka dumka. Kï̈, 35-47. = Кирик, А. 1990. Сковорода і грецька культура. Антична культура і вітчизняна філософська думка. Київ, 35-47. 
IRYNA KAIZER et al

Korž, G. 2017. Pid znakom Grigoriya Skovorodi: zoryanij čas ukraïnskoï kul'turi. Filosofiya osviti, 2 (21), 211-218. = Корж, Г. 2017. ПіА знаком Григорія Сковороди: зоряний час української культури. - Філософія освіти, 2 (21), 211-218. https://doi.org/10.31874/2309-1606-2017-21-2-211-218

Laslo-Kucyuk, M. 1990. Apofeoz svitla u tvorčosti Grigoriya Skovorodi. - Slovo $i$ čas, 3, 51-59. = Аасло-Куцюк, М. 1990. Апофеоз світла у творчості Григорія Сковороди. - Слово ічас, 3, 51-59.

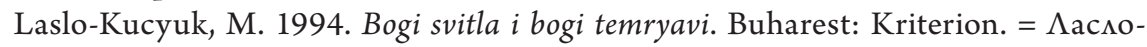
Куцюк, М. 1994. Боги світла і боги темряви. Бухарест: Критеріон.

Laslo-Kucyuk, M. 2000. Klyuč do beletristiki. Buharest: Mustang. = Аасло-Куцюк, М. 2000. К^юч до белетристики. Бухарест: Мустанг.

Marčenko, O. 2007. Grigorij Skovoroda i russkaya filosofskaya mysl' XIX-XX vekov. Issledovaniya i materialy. Moskva. = Марченко, O. 2007. Григорий Сковорода и русская философская мысль ХІХ-ХХ веков. Исследования и материалы. Москва.

Ničik, V., Šinkaruk, V., Stognij, I. 1997. Skovoroda Grigorij: obraz mislitelya. Kï̈v. = Нічик, В., Шинкарук, В., Стогній, I. 1997. Сковорода Григорій: образ мислителя. Київ.

Olyančin, D. 1992. Grigorij Skovoroda: doslidžennya, rozvidki, materiali. Kï̈v: Naukova dumka. = ОАянчин, А. 1992. Григорій Сковорода: дослідження, розвідки, матеріали. Київ: Наукова Аумка.

Popovič, M. 2007. Grigorij Skovoroda: filosofiya svobodi. Kï̈v. = Попович, М. 2007. Григорій Сковорода: філософія свободи. Київ.

Šapovalova, A. 2013. Tvorčist' Tarasa Ševčenka i filosofiya Grigoriya Skovorodi: dva vimiri svobodi. - http://www.univ.kiev.ua/pdfs /shevstud-16/24_Shapovalova_A. pdf (30.07.2021). = Шаповалова, А. 2013. Творчість Тараса Шевченка $i$ філософія Григорія Сковороди: два виміри свободи.

Ševčuk, T. 2010. Antična spaď̌čina v hudožnij recepciï Grigoriya Skovordi: avtoreferat disertaciï na zdobuttya včenogo stupenya doktora filologičnih nauk. Kiïv. = Шевчук, Т. 2010. Антична спадщина в художній рецепиії Григоріл Сковороди: автореферат дисертації на здобуття вченого ступеня доктора філологічних наук. Київ.

Soforonova, L. 2002. Tri mira Grigoriya Skovorody. Moskva: Indrik. = Софоронова,

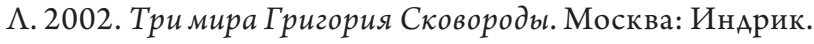

Uškalov, L. 1994. Svit ukraïns'kogo baroko: filologični etyudi. Harkiv: Oko. = Ушкамов, А. 1994. Світ украӥнського бароко: філологічні етюди. Харків: Око.

Uškalov, L. 2001. Ukraïns'ke barokove bogomislennya. Sim etyudiv pro Grigoriya

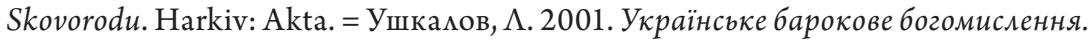
Сім етюдів про Григорія Сковороду. Харків: Акта.

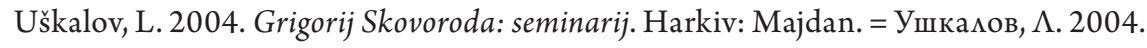
Григорій Сковорода: семінарій. Харків: МайАан.

Uškalov, L. 2007. Skovoroda ta inši. Pričinki do istorï ukraïnskoï literaturi. Kiïv: Fakti. = Ушкалов, А. 2007. Сковорода та інші. Причинки до історії української мітератури. Київ: Факти. 